of Fresh products, a Dra. Maria José Sousa-Gallagher, portuguesa, mas residente na Irlanda, onde trabalha no University College Cork. De referir ainda que, no decorrer do encontro, teve lugar a reunião da Divisão de Química Alimentar da SPQ, onde se decidiu que o encontro seguinte decorrerá em 2014 em Lisboa e será organizado pelo Centro de Engenharia dos Biossistemas, Instituto Superior de Agronomia (CEER-ISA).

Para o sucesso do 11EQA muito contribuíram os participantes com o seu dinamismo, bem como com a diversidade e número de trabalhos de elevada qualidade científica apresentados, que deixaram bem patente o interesse e relevância dos temas que centrali-

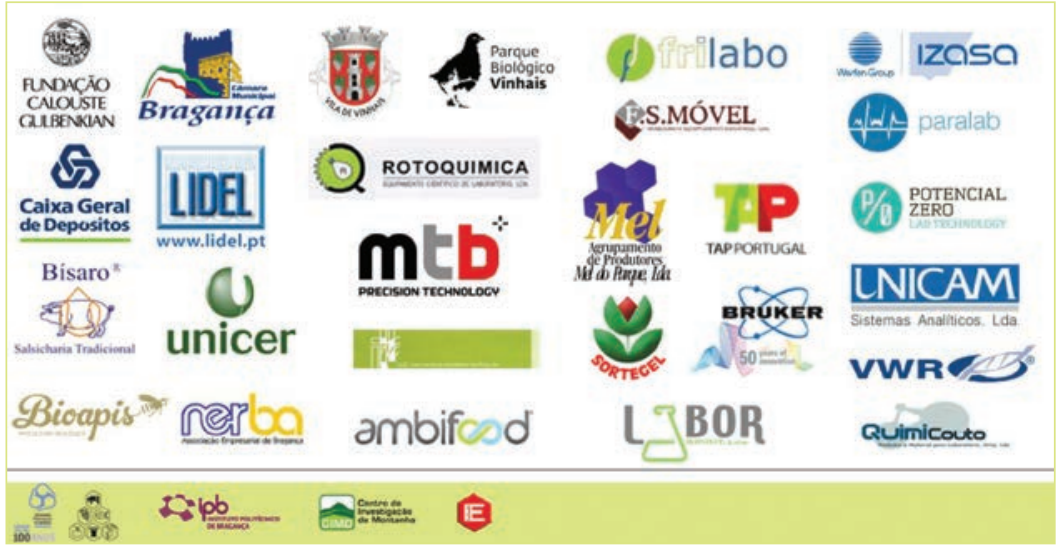

zaram as atividades deste encontro. Os patrocínios e apoios concedidos pelas mais diversas entidades e empresas, a quem a Comissão Organizadora dirige um sincero agradecimento, foram igualmente determinantes para o sucesso do encontro! Não podemos deixar de dirigir uma palavra especial de agradecimento ao apoio concedido pela Câmara Municipal de Bragança, NERBA e Fundação Calouste Gulbenkian, bem como para todas as empresas agroalimentares que de diversas formas apoiaram a realização do encontro, todas as empresas de equipamentos e reagentes de laboratório, com especial destaque para as que estiveram presentes com stands, e todas as demais instituições que nos deram o seu apoio.

Joana Amaral

(jamaral@ipb.pt) Comissão Organizadora

\title{
XXIV IUPAC SYMPOSIUM ON PHOTOCHEMISTRY
}

Realizou-se, nos dias 15 a 20 de julho de 2012, na Universidade de Coimbra, o XXIV IUPAC Symposium on Photochemistry, um evento que teve o apoio da Sociedade Portuguesa de Química. À semelhança dos Simpósios precedentes, o IUPAC Symposium foi um êxito consubstanciado nos 640 participantes, provenientes de 53 países. As maiores delegações presentes no evento foram a portuguesa, a japonesa e a espanhola, com 94, 93 e 72 participantes, respetivamente. Há ainda a destacar que metade da delegação portuguesa foi constituída por alunos de pós-graduação. Estes fac- tos são representativos do impacto da comunidade portuguesa de fotoquímicos e fotofísicos no desenvolvimento atual e futuro da Ciência em Portugal. O Simpósio iniciou-se no dia 15 de juIho com uma receção de boas vindas no Museu da Ciência, em que todos os participantes puderam disfrutar não apenas do espólio do Museu, mas também do ambiente único proporcionado pelo edifício Pombalino. A abertura oficial decorreu no dia 16 de julho (Figura 1), tendo sido procedida por uma lição proferida por Gregory Scholes (Toronto, Canadá) sobre mecanismos quânticos para

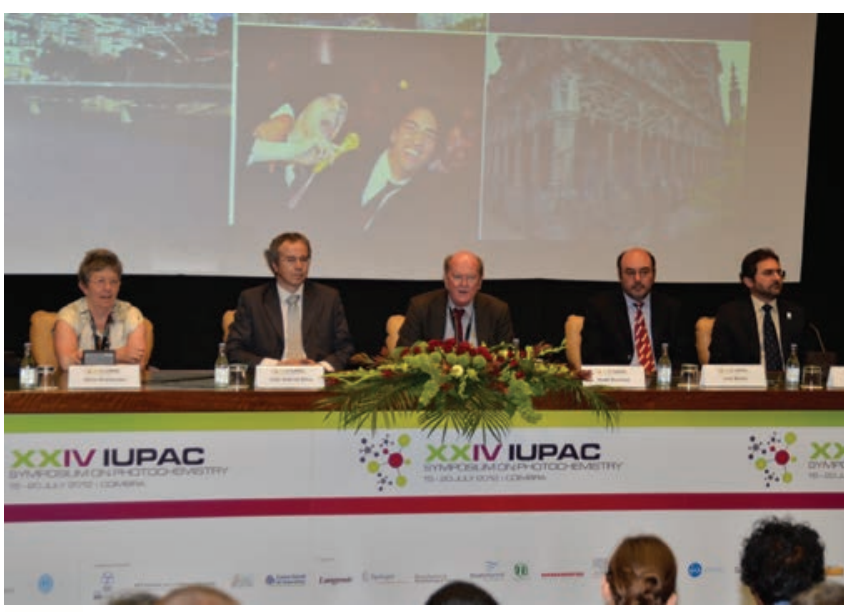

Figura 1 - Cerimónia de abertura, com a presença dos Profs. Silvia Braslavsky (IUPAC), João Gabriel (Reitor da UC), Hugh Burrows (Chairman), Luís Neves (Diretor da FCTUC) e Joaquim Faria (SPQ) (da esquerda para a direita) aproveitamento de luz na fotossíntese; as restantes lições plenárias foram proferidas por: Vivian Yam (Hong Kong, China), sobre organometálicos fotofuncionais; Guillermo Bazan (Santa Bárbara, Califórnia, E.U.A.), sobre aplicações de polielectrólitos e oligoelectrólitos conjugados em optoelectrónica e biolelectrónica; Anthony Harriman (Newcastle, Inglaterra), sobre antenas artificiais para captação de luz; Franco Scandola (Ferrara, Itália) abordou as estratégias supramoleculares para unidades funcionais em fotossíntese artificial; Ben Feringa (Gröningen, Holanda) proferiu uma lição onde reviu como controlar a agregação e o movimento através da luz; a lição proferida por Sebastião Formosinho e Luís Arnaut tratou da relevância do estudo de reações elementares na compreensão de processos fotoquímicos para o desenvolvimento de novas moléculas para a terapia fotodinâmica. O programa científico foi complementado com 22 lições convidadas, 111 comunicações orais, organizadas em 3 sessões paralelas, e cerca de 400 comunicações em painel. Os trabalhos apresentados focaram as mais diferentes áreas da fotoquímica, des- 